Stipe Grgas

University of Zagreb

\title{
Changing American Priorities: A View from the Ruins of Its "Communist Ally"
}

The author begins his paper by drawing attention to the absence of postsocialism in American Studies. This is peculiar considering that the establishment of the discipline was partly determined by the Cold War context, by the presence of socialism as its enabling other. Arguing for the need to differentiate both the former state of affairs and what has ensued after the demise of the socialist world, the author chooses to tackle the issue from the perspective of former Yugoslavia which had an "anomalous" position in relation to the United States. The crux of his argument hinges on the contention that both that position and what befell Yugoslavia have to be viewed within the unfolding of different times of capital. In his analysis the author puts an emphasis on the consequences of the so-called Nixon shock and the introduction of the incontrovertible dollar. In his conclusion the author puts forward a number of proposals how an engagement with these issues has consequences for the very definition of American Studies as a scholarly discipline.

Key words: Key words: postsocialism, Yugoslavia, geopolitics, American aid, finance, the Nixon shock

It is precisely because the money form of value is its independent and palpable form of appearance that the circulation form $M \ldots M$, which starts and finishes with actual money, expresses money-making, the driving motive of capitalist production, most palpably. The production process appears simply as an unavoidable middle term, a necessary evil for the purpose of money-making. (This explains why all nations characterized by the capitalist mode of production are periodically seized by fits of giddiness in which they try to accomplish the money-making without the mediation of the production process.) Karl Marx, Capital (II: 137) 
In an earlier paper, I drew attention to the fact that American studies are never merely an archival practice, but that they always engage in the actuality of their object of study. ${ }^{1}$ Drawing upon my earlier formulation, the object of American studies is not an ethereal thing, but rather a socio-economic entity whose transformations have intermittently intervened into the discursive field of the discipline (Grgas 2014a). More than other scholarly endeavors, American studies attunes both its content of inquiry and its methodology to the exigencies of the present moment. This can be seen when practitioners refer to a contemporary event or phenomenon in arguing for the relevance of their reading of America. As far as the early practitioners of the discipline are concerned, I am referring to those deictic marks which indicated the time of their writing. ${ }^{2}$ The same gesture can be more subtle and complex. Thusly the new Americanists registered the racial, ethnic, and gender fragmentation of the United States that was contemporaneous with their scholarly efforts. The same can be said for one of the latest transformations in the discipline, the socalled transnational turn, which emerged when it became more than obvious that to speak of the United States and to set it apart from the hemispheric and the global context was untenable.

Since this latest development provides the immediate context from which my deliberations proceed, I quote Winfried Fluck, who questions

1 The essay is part of research conducted in the project "A Cultural History of Capitalism: Britain, America, Croatia" funded by the Croatian Scientific Foundation (HRZZ-1543).

2 A cursory glance at some of the pioneering texts of American studies illustrates this practice. I have in mind, for example, Miller's locating and dating his "sudden epiphany" ... "of the pressing necessity for expounding" America to the twentieth century "at Matadi on the banks of the Congo" during WWII (vii). In The American Adam, Lewis remarks, "We can hardly expect to be persuaded any longer by the historic dream of the new Adam" (10). Henry Nash Smith does the same thing in the second Preface to Virgin Land, when he writes that, in 1969, Congress "is still markedly influenced by the now archaic myth of the Garden” (x). Finally, I note that Leo Marx, in the epilogue to The Machine in the Garden, states that "our inherited symbols of order and beauty have been divested of meaning" (364). 
some of the conclusions that scholars working within the transnational turn reach. Fluck concedes that the American national identity "may be temporarily in crisis," acquiescing in this manner to the supposed demise of the nation state in the latest phase of globalization, but then goes on to state that "the United States are a paradigmatic, agenda-setting modern society, and no talk about the crisis of the nation-state can distract from the fact that there is enough nation-state left to affect all of us decisively" (73). I will return to the question of whether "there is enough nation-state left" in the United States and address the implications this question has for the discipline of American studies, but before doing so, I will position my reading and map it onto a space which has been eclipsed and sidetracked even by those who profess a transnational perspective. I am referring to the absence of the post-socialist world and to the, in my opinion, insufficient attention which has been given to the event of 1989 and the demise of the socialist world in American studies and elsewhere.

That inattention is paradoxical, considering that the trajectory of American Studies was from its very beginnings powerfully determined by the bipolarity of the Cold War. From the archives which show how American studies emerged within that historical conjecture and how it was constituted as an antipode to the ideology of the socialist world, I draw upon Michael Denning's study The Cultural Front. Succinctly put, Denning argues that American studies were conceived as "the quintessential alternative to Marxism itself, which was understood simply as Soviet ideology" (446). If the constitution of the discipline owed so much to this antipodal logic, it is puzzling that the demise of the socialist world and the debacle of its ideology has not elicited a greater response. If the collapse of the Soviet Union and, as Ann McClintock puts it, "the enemy deficit" (92) has prompted disciplinary self-questionings ${ }^{3}$, these have largely been turned inward and have paid little

3 One must mention Donald Pease in this context and his "rethinking" of some of the tenets of American studies after the end of the Cold War. I cite an article in which the gerund in quotation marks above refers to one of these fundamental tenets, namely to the notion of exceptionalism: "The standpoint from which I had conducted this analysis correlated the 
heed to post-socialist realities, what preceded them and what role the United States played both in bringing about these realities and in structuring the earlier formation.

One reason for this inattention is that the event of 1989 has not been assigned the significance that it historically deserves. Without repeating past discussions of what constitutes an event, I refer to Phillip E. Wegner, who, in his study of the "long nineties" compares the "toppling of the World Trade Center" with the fall of the Berlin Wall in November 1989 and judges that the latter fall - and not 9/11 - was a true event. He adds: "unexpected and unplanned for, an encounter with a traumatic Real, it instigated a sequence of actions that would culminate two years later in the dramatic collapse of the Soviet Union and the subsequent end of the Cold War" (24). ${ }^{4}$ Primarily addressing an American readership, Wegner dethrones 9/11 as the inaugurating event of the present and antedates its genealogy to the dismantlement of the bipolar world. Inhabitants of the post-socialist world ought to give due weight to this reconfiguration of historical priorities. They will recognize the globalization of the local event of 9/11 as the imposition of an American reading of recent history that has only a tangential bearing on their condition. To fathom this condition they ought to search for different antecedents and ask why they have all too frequently brushed aside these antecedents when accounting for the emergence of the contemporary moment. Identifying the position of my writing as a site within the post-socialist world, I argue for the

\footnotetext{
US disavowal of its imperial history with the Cold War state's need to represent the US as uniquely positioned to oppose the imperialist ambitions of the Soviet Union. During the Cold War, the discourse of American exceptionalism had legitimated America's dominance within a dichotomized world order by supplying the rationale for America's moral superiority to Russian communism" (19).

4 Wegner theorizes the concept of the event by calling upon Alain Badiou and Slavoj Žižek. He quotes Badiou's description of the event as something that happens "that cannot be reduced to its ordinary inscription in 'what is there,", something that is the "void of the situation, that aspect of the situation that has absolutely no interest in preserving the status quo as such" (23). All of these qualifications are, I think, applicable to the fall of the socialist order.
} 
epochal significance of the collapse of the socialist world - or, put otherwise, the restoration of capitalism - when confronting the reality in which I put forward these observations. ${ }^{5}$

Shu-mei Shih's explanation for why the post-socialist experience and what triggered it did not receive serious attention is pertinent to American studies and hints at the parochialism of the discipline as practiced in the States. In the article "Is the Post- in Postsocialism the Post- in Posthumanism?" we read:

The apparent inapplicability of the postsocialist framework to the West ... is the major reason for the general lack of interest in the topic in American academia, where the discussions of postsocialism are largely confined within the now nominally debunked but actually existing area studies, the assumption being that it lacks universal significance. (28)

I add that not only has the project of socialism itself been delimited to an area but to a history whose relevance has been systematically downplayed in the latest conjuncture. These amnesia-inducing displacements were part of a strategic move in a totalizing setup that now promotes itself as being without an alternative. Therefore, the passing away of a world that purported to be paving the road to a system antipodal to capitalism - to be forthright about

5 Agnes Heller and Ferenc Feher provide an interesting reading of what was at stake in this historical transformation. They work with the notion of "radical universalism" - under which they subsume Marxism - and contend that it was "one of the most significant and most influential visions in the period of high modernism, that is, between the end of the nineteenth century and 1968 ... The symbolic year of 1968 was a watershed in an already unfolding process. Post-modern attitudes replaced the high modernist ones in arts, literature, as well as in the vision of the world" (5). The pertinence of these remarks to my argument is evident on the next page: "Radical universalism became history altogether in the glorious year of 1989. In this respect, although in no other, 1989 is Eastern Europe's 1968 " (6). The breakup of Yugoslavia could easily be put forward as evidence that their "pessimistic scenario" of the resurrection of "radical particularism" after the default of "radical universalism" was not confined to theory but played itself out in a catastrophic "praxis" (Heller \& Feher 3). 
it - was relegated to a mere blip in the inevitable unfolding and ending of history. Shu-mei Shih provides another take on the matter which adumbrates a number of issues that I deal with below:

postsocialism ought to be considered as a condition affecting the entire world. The collapse of the Soviet Union and the end of the Cold war reconfigured the world in specific ways. For instance, the Cold War divided the world around a particular kind of dichotomy of East and West - socialism and capitalism - not the East and West of Orientalism and Occidentalism. The collapse of this dichotomy has given rise to a new dichotomy with a different geographical pivot - the North and the South - as a way to understand the economic inequality in today's world. The end of the Cold War, furthermore, greatly hastened the onward march of the neoliberalization of the entire world in economy and politics. (28-29)

If recent developments - demographic movements, terrorism, rising inequality - indicate a tectonic change, then the demise of the socialist world must, in my opinion, be indicated as one of the historical determinants. Parenthetically, I add that I am not implying direct causality but rather an enablement of processes by default.

In what follows I focus upon a site that was and was not a part of the socialist world. In doing so, I hope to illustrate the need for a nuanced approach to both the socialist world and to its breakdown. The fact that this site - Yugoslavia - had a different relationship to the United States than did other socialist countries is the departure point of my paper. In what follows I will outline the nature of this relationship during three different periods. Furthermore, I will show that the positioning of the United States towards Yugoslavia reflected mutations in the U.S. polity itself. I will contend that those mutations have more to do with the economic sphere than with any other facet of the United States. Put otherwise, the history of United States' presence in Yugoslavia and in the region after the breakup of the federation reflects the changing nature of the American economy. In my conclusion I will field some thoughts about what the future holds for the discipline of American studies and how the discipline ought to respond if issues of the economy are prioritized. 
The syntagm "American Communist ally" was coined by the Croatian historian Tvrtko Jakovina for the title of his study of U.S.-Yugoslav relations during the period 1945-1955. Jakovina documents the substantial aid the United States provided to Yugoslavia as part of its policy of containing Soviet expansion (Jakovina). The status that Yugoslavia enjoyed as a by-product of this policy - a commitment to Marxist ideology ${ }^{6}$ coupled with ties to the West - made it an anomaly in the bipolar world and therefore perhaps hard to subsume under the dichotomy that we saw contributed to the rise of American studies but nevertheless an anomaly that exemplifies a law of American involvement abroad. Simply put, if we do not abdicate in relation to economics, ${ }^{7}$ we will see that Yugoslavia's anomalous condition was sustained by powerful, American-sponsored material-financial circuits and flows. I intend to show that these circuits and flows were not static but reflect both quantitative and qualitative mutations both in the ally and in the United States itself. For simplicity's sake I summarily divide American relations to Yugoslavia into three periods: (a) the period before the breakup of the former federation, (b) the period of the breakup itself, and (c) the period of dismantlement. I do so not because I intend to give an exhaustive description of each period but,

6 Agnes Heller and Ferenc Feher provide an interesting reading of what was at stake in this historical transformation. They work with the notion of "radical universalism" - under which they subsume Marxism - and contend that it was "one of the most significant and most influential visions in the period of high modernism, that is, between the end of the nineteenth century and 1968 ... The symbolic year of 1968 was a watershed in an already unfolding process. Post-modern attitudes replaced the high modernist ones in arts, literature, as well as in the vision of the world" (5). The pertinence of these remarks to my argument is evident on the next page: "Radical universalism became history altogether in the glorious year of 1989. In this respect, although in no other, 1989 is Eastern Europe's 1968 " (6). The breakup of Yugoslavia could easily be put forward as evidence that their "pessimistic scenario" of the resurrection of "radical particularism" after the default of "radical universalism" was not confined to theory but played itself out in a catastrophic "praxis" (Heller \& Feher 3).

7 I am rephrasing Bernard Stiegler's diagnosis that "the philosophy of our time has abandoned the project of political economy". I fully agree with his pronouncement that, "because it is true that economism has led to horrific outcomes, nevertheless the absence of a critique of today's economy prepares other horrors" (18). The later section of my paper takes up "current economics" which I think played a part in the horrors that attended the breakup of Yugoslavia and the travails of its post-socialist reality. 
keeping the American Studies perspective in view, to propose that the differences between the three periods reflect a mutation of economics that affected both the United States and the historical trajectory of its ally.

\section{2}

Tvrtko Jakovina's study of the aid the United States gave to Yugoslavia after Tito broke with the Soviet camp can be supplemented by other authors. One can, for example, go to David A. Dyker, who writes: “The $\$ 650 \mathrm{~m}$ worth of US food aid given to Yugoslavia 1950-9 not only helped Yugoslavia to survive the dark days of the early 1950s, but also enabled it to run a deficit on agricultural Balance of Trade 1953-9 averaging \$40m annually” (45). For the purposes of my argument, it has to be said that this sort of aid was discontinued in 1961, but as Dyker makes clear, this did not mean that the United States had lost interest or disengaged itself from its "ally." As Dyker reveals, the opposite was the case: "there can be no doubt that the dominant American position within the IMF, and particularly within the World Bank, helped to insure that the flow of capital import would not be seriously interrupted" (157). That position of dominance, to paraphrase Dyker, will be the main issue when I turn to the question of United States' agency and power in the present conjuncture, but for now it suffices to say that America's presence in Yugoslavia was mediated, after the initial aid packages, through institutions that one does not immediately identify with the United States.

Due to its "anomalous" position, Yugoslavia was the favorite country for receiving IMF funds in Eastern Europe. One of the charter members of the IMF, Yugoslavia only went three years without taking out IMF loans in the period from 1949 to 1989 . The World Bank extended 2.7 billion dollars in loans from 1950 to 1980 (Asseto 46). Dyker updates that chronology: "In 1981 the IMF approved a three-year credit of $\$ 2.2 \mathrm{~m}$ for Yugoslavia. At that time it was the biggest IMF loan ever, and it represented a milestone in Yugoslavia's relations with the international financial community" (122). According to Dyker, the point of crisis arrived in July 1987 "when Yugoslavia found herself unable to meet debt repayments totaling $\$ 240 \mathrm{~m}$ ” (158). In 
1988 "with Yugoslavia entering into new commitments to the IMF to liberalize and rationalize her economic system, things seemed to get worse rather than better" (153). With hindsight we know that Dyker understated the gravity of the matter.

Needless to say, this stark chronology is more than reductive. But it will do to introduce an explanation of the breakup of the former federation that implicates American complicity. Writers who espouse such an explanation routinely point to changes in IMF and U.S. policy under the Reagan Doctrine and the shifting priorities of the U.S. after the fall of the Berlin Wall. In his article "How the IMF Dismantled Yugoslavia," Michel Chossudovsky goes so far as to say that "through their domination of the global financial system, the Western powers, in pursuit of national and collective strategic interests, helped bring the Yugoslav economy to its knees and stirred simmering ethnic and social conflicts" (Chossudovsky). In Balkan Tragedy, Susan Woodward provides a more analytic explanation of the Yugoslav story:

The problem was shortage of foreign currency, although experts blamed distortions in the economic system. The immediate solution was to seek shortterm coverage (through IMF credits) ... Terms negotiated with the IMF [were] railroaded through a tumultuous federal parliament ... This project was completed by 1985 , when the second stage of the debt crisis program began. The second stage was to legislate economics reforms on the basis of a "long-term program for economic stabilization" created by external creditors and an ad hoc commission of economists and politicians ... (1995: 50-51, 57)

From Woodward's works on Yugoslavia, I quote an observation about the pivotal point of those reforms which indicates how the initial privileged geopolitics of Yugoslavia disappeared after the fall of the Berlin Wall:

Despite the clear success of Prime Minister Markovićs economic reform and his personal popularity in the country, neither the US nor the European Community states were willing to loan the instalment necessary in the spring 
of 1991 to pay the interest on the Yugoslav foreign debt and keep economic reform on track. The contrast at the same time with Western aid to central Europe - Poland, Hungary, and the Czech Republic - is striking. (2003: 85-86)

Although it is disputable whether in the spring of 1991 Yugoslavia was still a viable polity, I find no other source that has highlighted the contrast Woodward makes, nor do I recall that it surfaced during the death throes of Yugoslavia. For much too long its peoples had been persuaded about the strategic importance of the country, and that discourse continued in modified forms during the breakup of the federation and afterwards. To acknowledge that historical events had deprioritized the region to insignificance demanded a leap of the imagination or a sobering taking stock of a newly-created reality which neither the people nor their political leaders were capable of performing.

Gesturing to these imaginaries, I indicate that I do not wholeheartedly embrace economic explanations of the breakup of Yugoslavia. However, I add that any explanation which does not take the economy into account is short-sighted. ${ }^{8}$ It is true that the politicians responsible for the breakup downplayed economic issues and legitimated their policies on other grounds. As a

8 A part of that economic explanation would have to take into account the fact that the time when Yugoslavia took out loans was a time of easy money. I cite Massimo Amato and Luca Fantacci's book The End of Finance: "From the end of the 1970s on, the volume of capital movements, in particular towards developing countries, has increased exponentially. This, too, is a phenomenon that can be described in terms of increasing credit accessibility for agents who belong, in this case, to whole countries, geographical areas or economic sectors previously excluded from the international financial system: we might call them the 'planetary subprime borrowers" (78-79). That "accessibility" returned at the turn of the century and accounted for the upbeat economic indicators before the outbreak of the crisis in 2008. In his study of international finance, Eswar S. Prasad speaks of "go-go years" when "taking on debt and then rolling it over into new debt seemed like a cinch, so policymakers in developing countries were not too concerned about rising debt levels" (53). Explicitly referring to the post-socialist world, Prasad notes that "emerging markets in Eastern Europe had become more reliant on foreign bank loans before the crisis. Western European banks established a dominant presence in many of these countries and financed the region's domestic demand boom before the global financial crisis" (58). 
consequence, the cost and benefits of nationhood - of war, to be more specific - were muted amidst the euphoria of identity politics. ${ }^{9}$ But with hindsight one easily recognizes that the economic determinant was always there. For example, if due weight is given to the dynamics of loan and debt and how the distribution and the collection of these always has a price, Yugoslavia was not an anomaly but can serve as a lesson. ${ }^{10}$ David N. Gibbs holds that programs of structural adjustment imposed on Yugoslavia were motivated by Western forces to get back their loans without paying heed to the social and political consequences. He calculates that the cancellation of the Yugoslav debt would have been less costly than the expenditures for the later military intervention in the 1990s (Gibbs). ${ }^{11}$ Needless to say, even bringing up the possibility of the cancellation of debt in today's world is a heresy. That orthodoxy with its leitmotif that "there is no alternative" continues to hold. ${ }^{12}$ The United States,

9 David A. Dyker recognized Slobodan Milošević as "a populist, even a rabble-rouser" but noted that "the most striking characteristic of the Milošević phenomenon was its lack of a serious economic policy dimension" (182). The paradoxical absence of the word "capitalism" or of economic issues in general during the turbulent 1990s in the Yugoslav region shows how the ideology of identity hid the looting that was taking place behind the scenes.

10 Vladimir Gligorov, an economist who is doubtlessly fully informed of what transpired in ex-Yugoslavia, has noted how Yugoslavia's experience with debt can help one understand the plight of Greece (Gligorov).

11 Writing this amidst the immigrant crisis and watching the border troubles of the incoming people, I cannot help but think how their path would have been much easier if the former polity had not been fractured. In a less ironic tone, in these trying times when the disruptions in the Middle East and in Africa are tragically impacting the world, I cannot but think of the position Yugoslavia held in the non-aligned world and how that movement provided a forum for articulating the interests of the Third World. That forum today does not exist, and its absence has brought onto the geopolitical stage dangerous players who pose the gravest threat to the world. With historical hindsight it is justifiable to say that the demise of the non-alignment movement was not the godsend certain strategists thought it to be.

12 It is interesting that the fiercest upholders of that orthodoxy come from Germany, which itself greatly benefitted from its own cancellations of debt. Albrecht Ritchl has shown that cancellations of Germany's debt in the 1950s "was worth as much as four times the country's entire economic output in 1950 and laid the foundation for Germany's fast post-war recovery". In a telling comparison he showed that the debts of today's struggling Eurozone economies “were equal in size to Germany's current gross domestic product. In 
or rather, its politicians and economists, played and continue to play an important role in the implementation of this orthodoxy, although, as will become clear, they waive its dictates when the American polity is in question.

\section{3}

The ruins of socialism, of an order seemingly proven unviable and defunct by the very logic of social development, were visited by experts from the West who fielded proposals and implemented them to supposedly set right the aberrations of the socialist states. These proposals were codified in the so-called "Washington Consensus,"13 whose very name testifies to its place of origin and empowerment. David Ellerman offers a critique of the actions of these experts that is pertinent to the American studies problematic:

in this context, "Western" seems to mean "American" (or Anglo-American). German or Japanese economists seem to have felt uncomfortable as intellectual evangelists (or "imperialists") preaching to the post-socialist countries

other words, debt cancellation for the Eurozone would be equivalent to the debts that were cancelled by the Allies after World War II" (Ritchl). Of greater relevance to my argument is the fact that in 1991 Western governments agreed to forgive about half of the $\$ 33$ billion piled up by Poland's Communist-era governments. They did not do this out of charity. Peter Gowan gives an explanation which supplements Susan Woodward's puzzlement at how the West treated Yugoslavia at about the same time the Polish cancellation took place: "The Bush administration's scheme would make NATO necessary to consolidate the absorption of East Central Europe and thus assure US leadership. The likelihood of EU resistance to the US assault on its CAP and trade regime would make the US the champion of the economic interests of the belt of states between Germany and Russia. In this context, Poland was the geopolitical key and it also had a new elite strongly orientated towards US neo-liberal values and able to draw on a long-standing fund of Polish sentiment sympathetic to America. The cancellation of Polish debt, amongst other things, becomes explicable only in this political context" (241). Just as this passage points to issues pertinent to American studies, it is even more relevant to understanding the deprioritized position of Yugoslavia after the fall of the Berlin Wall.

13 John Williamson gives a list of its main tenets: fiscal discipline, public expenditure priorities, tax reform, financial liberalisation, exchange rates, trade liberalisation, foreign direct investment, privatisation of state-owned enterprises, deregulation of economic activity, and property rights (26-28). 
even though they may actually have more relevant experience to offer than their Anglo-American counterparts. Only the mixture of American triumphalism and the academic arrogance of neo-classical economics could produce such a lethal dose of gall. If the economics of Pinochet's Chile was attributed to the "Chicago Boys", then the economics of Yeltsin's Russia might be attributed to the "Harvard Wunderkinder." (Ellerman 32)

Although the problem these advisers set out to solve was something that had never before happened in history - the transition from socialism to capitalism - they were not fazed by the enormity of the task. On the contrary, they held steadfast to their ideas and rejected all opinions which pled for caution or gradual changes. As Ellerman writes: all reformers who pled for "incrementalism were undercut by the shock therapy advice of the Western professors" (33). One of the foremost spokesmen for shock therapy was Jeffrey Sachs, who played an important role in developments in Russia and in Poland. ${ }^{14}$ It is less known that he advised Ante Marković before the breakup of Yugoslavia, helping the government prepare the IMF/ World Bank "shock therapy" package which was then introduced in 1990 just at the time when parliamentary elections were being held in various republics. ${ }^{15}$ The results of

14 A vignette provided by Branko Milanović, a Yugoslav economist at the World Bank, reveals how Jeffrey Sachs saw himself during the period of transition. Milanović recalls how he met Sachs in a bookstore and how Sachs asked Milanović to sign a copy of Milanović's new book: "I thought for a second and wrote: 'To Jeff Sachs, who is trying to save socialism. Jeff was kind of shocked, and he said, 'I do not want to save socialism; I want to bury it'. I was surprised then but realized later: I was still behind the curve regarding what was happening. I saw the early reforms in Poland as a way to introduce market elements into socialism, the same way that Keynesian economics introduced some state into capitalism. Pushing the parallel further, I saw the socialist crisis of the 1980s as a way toward the creation of a reformed and sustainable socialism. But Jeff (rightly) saw it as the end of socialism and the beginning of the transition to capitalism" (quoted in Bockman 158).

15 It is rarely recorded that Marković had another home-grown option for reform. In his book on Yugoslavia, Viktor Meier felt the need to mention it in his account: "Professor Alexander Bajt in Ljubljana had been active at the time as adviser to Marković, together with two other economic experts, Dragomir Vojnić and Kiro Gligorov. This trio had, in summer 1989, more or less completed work on a concept of economic reform: it would 
those elections are well known. I will add that he was later an advisor to the government of Slovenia. ${ }^{16}$

The question that needs addressing is whether the policies that were proposed and implemented in the post-Cold War period were different from earlier policies that, we saw, enabled Yugoslavia's "anomalous" position. To answer that question I think it is justifiable to see the United States' aid packages to Yugoslavia as something that, although not a part of the Marshall Plan, took place under its policy of containment. The difference that I want to emphasize between the two periods of United States involvement is summarized by Paul Starobin: according to Starobin, the Marshall Plan people were "men of practical, worldly experience" whereas "post-Cold war planners were pre-eminently men of theory." Starobin elaborates on this distinction:

The post-Cold war planners were principally interested in social engineering, in building an edifice of pluralism - a way of life that incorporates democracy, freedom of expression, and market-oriented economies - in lands that had mostly lacked such structures. The Marshall planners had the more modest aim of helping Western Europe rebuild its physical core - its roads, bridges, and factories. (Starobin)

Whereas earlier American policy-makers "operated in a domestic po-

have been less radical, but nonetheless comprehensive. As early as September or October it had become clear, however, that Marković had decided for a 'shock therapy' along the lines of Sach's ideas. As a result, Bajt resigned at the end of November 1989, as Marković pushed forward with his own plans. The reliance on Sachs contributed to the fact that Marković would later be treated as a hero by Western diplomats" (105). My colleague Sven Cvek drew my attention to the existence of this source.

16 Jeffrey Sachs has evolved in his economic thought and has retracted from the orthodoxy of shock therapy. One of the surprising stages of these transformations can be deduced from Yanis Varoufakis' recent comment about an alternative plan for Greece: "We had such a plan. In March, I undertook the task of compiling an alternative program for Greece's recovery, with advice from the economist Jeffrey Sachs and input from a host of experts, including the former American Treasury Secretary Larry Summers." One can only say: strange bedfellows. 
litical culture, shaped by the great depression and the New Deal," that had concluded that unbridled capitalism was a recipe for economic catastrophe, the "Big Bangery" of the new economic evangelists "fit the prevailing conventional wisdom of post-Reagan America - the idea that markets and not governments are the surest guarantors of not only prosperity but political freedom and stability as well" (Starobin). Thusly we see that two different Americas projected their policies abroad during two historical points in both of which the United States played a decisive role.

I am tempted to use two archetypes from American literature and say that in the earlier period the policies were Starbuckian, while in the post-Cold War period, Ahab commands the helm. The point that I want to stress is that the difference was dictated not only by changed geopolitical circumstances but by transformations within the United States itself. Summarily stated, the earlier productivist ethos was displaced, and in its stead there now reigned and still reigns the command of money. The nature of that command will be outlined in the next section, but what cannot be doubted is its global reach and its intention to eradicate everything that stands in its way. Marie Lavigne comments on "Big Bangery" in a manner that anyone who has lived through the transition period in post-socialist countries easily recognizes: "Big bang' or 'cold turkey' programmes express an intellectual and political commitment to a monetarist, neo-classical vision, along with a willingness to radically break away from the past. The big bang is a kind of insurance against any temptation to look for a 'third way' (any version of 'market socialism')" (119). The command of money, debt, and shocks of austerity are being given full sway, while systematic amnesia works hard to erase remnants of an alternative world. ${ }^{17}$ An American studies that is willing to address these is-

17 Some readers might contend that in Croatia capitalism was never fully restored and that to speak of the power of capital here misses the point. Such views do not recognize the fact that the power of capital/money works not only when it is present but when it chooses not to invest in a certain site. Croatia's present is swamped by talk of investment and capital and what many diagnose as the basic problem of its economy can be described as an "investment strike" (Panitch and Gindin 61). Peter Gowan helps us understand what 
sues must go to its object of study and ask about the position of the United States in this constellation. It will ask, to formulate the question in terms of my Melvillean archetypes, whether the Pequod, indebted and with so many of its hands idle or not manufacturing things that were its long-time forte, is on a course to meet its whale. However, as the next section will show, analogies with other debt-ridden polities do not hold, and what proved destructive of, for instance, its one-time ally has turned out otherwise with the United States.

\section{4}

In order to explain this difference, I will add to my opening description of disciplinary practice - the deictic marks of the time of the writing - another methodological ploy. That is, just as American studies are always attuned to the present moment of their object, the disciplinary archive shows that, in order to explain that moment, its practitioners select this or that historical period as the formative, originative moment of the present of the American project. In my last book (2014b) I argued that, in order to understand the United States today, it is necessary to recognize the decisive impact of the 1980s on subsequent developments both in the United States and elsewhere. Both my description of Yugoslavia and the American interventions in the post-socialist world seem to justify assigning to the 1980s this significance. If the new mutation of the economy can be summarized as a period witnessing the ascendency of finance - a contention I take here for granted - I am merely rehearsing extant explanations and periodizations. To take but one example, Giovanni Arrighi assigns a formative role to that decade:

With the advent of the Reagan era, the "financialization" of capital, which had been one of several features of the world economic crisis of the 1970s,

is at stake when he distinguishes between the productive sector and the financial sector and holds that the latter is dominant because "it decides where it will channel the savings from the past and the new fictitious money - who will get the streams of finance and who will not" (13). 
became the absolutely predominant feature of the crisis. As had happened eighty years earlier in the closure of the demise of the British system, observers and scholars began once more hailing "finance capital" as the latest and highest stage of world capitalism. (ix)

Let me here ask the reader to return to my epitaph. In Marx's terms, financialization would mean a constellation where the circuit of capital dispenses with the middle turn - commodity production - and the process of valorization is embedded in money-making itself. In the Penguin edition of Capital, Volume II, we read that the sentence in parentheses was introduced by Engels. If that is so, we can say that Engels has extrapolated from Marx's argument a possibility opened to capitalist polities but in his phrasing ("fits of giddiness") implies that this possibility is an unsustainable anomaly. I revisit the issue of financialization here not only because the parallel between these anomalous states - their "fits" - and their foredoomed plight (as Arrighi states for the British system) and the present condition of the United States seems not to hold but also to return to an event to which, although I do mention it (2014b: 45), I am not alone in not having assigned proper significance. It will be seen that, if the momentous nature of this event is recognized, we must assign to the United States a powerful agency in bringing about the present mutation of money.

Joseph Vogl maintains that there are three preconditions for today's economy. The second is liberalism, while the third precondition is technical innovation. However, the first precondition, one to which I now assign much greater significance than I did previously, particularly in light of my opinion that it is foolhardy to speak of American "declinism," has to do with finance. I quote Vogl:

A first precondition for our economic present surely lies at the beginning of the 1970s. I refer to the end of the Bretton Woods arrangement, that postwar order which responded to the great Depression by equipping the world economic system with a security mechanism: when all important currencies are 
bound to a fixed relation to the dollar, while the dollar is in turn bound to a fixed exchange to gold, the international trade of commodities and capital should remain crisis-free. For whatever reasons, this system failed (an essential reason being the United States' gigantic foreign debts), in 1971 President Nixon brought the so-called gold window to a close, and, in 1973, the Bretton Woods agreement was formerly laid to rest. Then arose so-called floating currencies and currency exchange rates, and in turn began what still bears on us today: the trade of foreign currency derivatives and financial derivatives, or the so-called practice of hedging. In order to protect against the faltering exchange rates in international trade, it seemed reasonable to insure the present with bets on future business cycles, that is, to force futures trading into currency markets. In other words, faltering currency exchange rates are insured (hedged) by currency futures contracts, and possible price differentials are hedged by bets on possible price differentials. The trade of financial derivatives is rapidly becoming the largest market overall; at the turn of the century it amounted to $\$ 100$ billion, triple the worldwide value sales on consumer goods. (136)

The importance of the closing of the gold-window is underlined by Michael Hudson: "The Nixon administration was playing one of the most ambitious games in the economic history of mankind, but it was beyond the comprehension of the liberal senators of the United States, and it did not appear in the world's economic textbooks" (410). Massimo Amato and Luca Fantassi also describe the Nixon decision as an epochal event: "In the performance of the very act with which Nixon, somewhat unwittingly, put an end to 2,500 years of history, a new era was ushered in, and a new currency: from now on the currency, the legal means to pay debts, would no longer be gold but anther debt" (89).

If the inauguration of incontrovertible money was beyond the comprehension of American policy makers, we can surmise that its effect passed under the screen of the majority of people both in the United States and abroad. Calling upon discourses only tangentially associated with the economy, George C. Caffentzis, in his article "Marxism and the Death of Gold," recalls 
how Nixon "taunted his Republican cronies by calling himself a 'Keynesian" and adds:

if he had had the vocabulary, he might have also enjoyed taunting them even more by describing himself as the first "postmodern" President. For if postmodernism has the rejection of representation as the defining element of symbol-systems, then he debunked the last monetary myth of reference: the dollar-gold convertibility enshrined in the Bretton Woods accords of 1944. 15 August 1971 was apparently the last act in the long, slow and intermittent saga of the elimination of referentiality from the monetary world. (in van der Linden 408)

If, as Heller and Feher maintain, 1989 was Eastern Europe's 1968 and its entry into postmodernism, we can say that it was unprepared for that entry. It was unprepared to realize, to quote Christian Marazzi, that "money has become the ultimate and most sophisticated instrument for world capitalist structuring today" (Marazzi). The question to ask is, Was America prepared for it? According to some, it was not only prepared, but the event which inaugurated the present, according to Joseph Vogel, was merely one of a long line of policy decisions that had created its state of preeminence.

From the perspective of American studies, the question that insinuates itself is: to what extent was the conjuncture brought about by the agency of the American polity? That is, to return to Fluck: was there enough state left in the emergence of this conjuncture? There are two possible answers. One is that the American state was very active in bringing about this conjuncture. In their preface to The Making of Global Capitalism: The Political Economy of American Empire, Leo Panitch and Sam Gindin state that "the spread of capitalist markets, values and social relationships around the world ... far from being an inevitable outcome of inherently expansionist economic tendencies, has depended on the agency of states - and of one state in particular: America" (vii). They summarize their argument in the following manner: "The American state has played an exceptional role in the creation of a fully global 
capitalism and in coordinating its management, as well as restructuring other states to these ends" (1). ${ }^{18}$

In his book The Global Gamble: Washington's Faustian Bid for World Dominance, Peter Gowan returns to the 1970s and the collapse of the Bretton Woods regime and disparages those who saw Nixon's decision as stemming from a "weakened American capitalism." He shows that the reality was different: "The Nixon administration was determined to break out of a set of institutionalized arrangements which limited U.S. dominance in international monetary politics in order to establish a new regime which would give it monocratic power over international monetary affairs" (19). Designating this regime "the dollar-Wall-Street regime," Gowan explores its consequences. At one point, he reminds his reader that, in the context of international money, "a state has to acquire funds of internationally acceptable money in order to be able to pay for goods and services abroad," so that a country has to earn (or borrow) an international currency, say the dollar, before it can buy anything from abroad. However, for the United States this rule does not apply; because the international currency is the dollar, it does not need to borrow dollars abroad: "it prints them at home!" (25). ${ }^{19}$

18 Concerning the former Yugoslav polity, we find in Panitch and Gindin the following observation: they write about "the grand opening to capital accumulation that '1989' represented in the USSR and Eastern Europe. The 'pioneering' lending strategies of Western banks had already combined with the sclerosis of 'actually existing socialism' to turn Poland, Yugoslavia, and Hungary, among other Communist states, into sizable debtor states during the 1970s, thereby initiating 'the renewal of East-West economic integration' through a new relationship between 'global capital markets and command economies. The Eastern European states were mostly cut off from new bank loans along with the Third World states that were so severely impacted by the debt crisis in the 1980s" (218).

19 Eswar S. Prasad calls this the "dollar trap". He points out that, although the 2008 financial crisis originated in the United States, it did not weaken the dollar or stop money inflows into the country. In brief, his explanation is the following: "The reason the U.S. appears so special in global finance is not just the size of its economy but also the fact that it has fostered a set of institutions - democratic government, public institutions, financial markets, a legal framework - that, for all their flaws, are still the ones that set the standard for the world" (13-14). I am not convinced by this benign explanation but offer it as a supplement to the more critical readings given by my other references. 
"Dollar seigniorage," as Gowan designates this setup, relates to Panitch and Gindin's designation of American Treasury bonds as the "safe haven" in today's world and their injunction that "the appreciation of which is inseparable from the role of the American state as the ultimate guarantor of global capitalist interests" (333). Michael Hudson gives us a similar take on the central role played by the United States in today's global order:

the United States paved the way by demanding that it be given veto power in any multilateral institution it might join. This power enabled it to block other countries from taking any collective measures to assert their own interests as they might be distinct from U.S. economic drives and objectives. I believe that at first the use of the U.S. payments deficit to get a free ride was a case of making a virtue out of necessity. But since 1972 it has been wielded as an increasingly conscious and deliberately exploitative financial lever. (36)

Elsewhere in Hudson, we read how American debt functions as a lever of power:

the United States is able to rule not through its position as world creditor, but as world debtor. Rather than being the world banker, it makes all other countries the lenders to itself. Thus, rather than its debtor position being an element of weakness, America's seeming weakness has become the foundation of the world's monetary financial system. To change this system in a way adverse to the United States would bring down the system's creditors to America. Widespread European and Asian fear of such a breakdown has enabled the United States to dominate the world economy through just the reverse process from that by which Britain ruled in the 19th century. (331)

Martijn Konings summarizes what this amounts to: "America's pivotal position in global finance and the dollar's role as the fulcrum of this system meant that America's debt to the world was in fact a significant power resource" (120). But having come to this point, I could have remained within disciplinary confines and simply turned to Donald Pease, for example, who 
from within the transnational turn writes:

The global economic order is not run by blind market forces; it is regulated by complex interventionist stratagems devised by the transnational institutions that the U.S. put into place during the Cold War. The Bretton Woods conference established a postwar international financial system that paved the way for the determinative role that U.S.-controlled institutions like the World Bank, the IMF, and the General Agreements on Tariffs and Trade (GATT) played in global economy. Despite its ostensible support of free-market ideology and opposition to state intervention, the U.S. government's integration of global management networks gave U.S. multinational corporations a competitive advantage in national markets. (25)

The reason that I resorted to economists was not only to ground these generalizations in concrete policies and date them to an epochal mutation of money but also to delineate the present, where "finance is now this collective image, surpassing nation-states with its capacity for the apprehension, objectification and creation of productive activity" (Holmes). It is obvious that this "surpassing" of nation states challenges those who, like the authors quoted above, assign a pivotal role to American agency.

If Pease provides an Americanist summary of the mechanisms of United States power, Brian Holmes's statement opens a propaedeutic which questions the agency of the object of American Studies that, if addressed, I think has implications for the discipline as such. That propaedeutic returns to the question of American agency and asks, Does the United States really oversee the dynamics of capital? Is it not possible to see its Faustian bid, for example, as "merely a cog," to use Marx's trope (1976: 739), in capital's "endless and limitless drive to go beyond its limiting barrier," to quote Marx again (1973: 334). Does not capital disable not only those who are victimized by its drive but also those who believe that they can make it subservient to their plans? Is that latter possibility not greater today than it was in the past, when volatile finance has achieved and daily achieves an unprecedented ascendancy? To merely hint at what I think is at stake, I quote from Suhail Malik's “The On- 
tology of Finance":

Constituted qua finance-power, capitalism is realised only in more or less local, more or less large power conflicts. It has no necessary operational, social, cultural, institutional identity nor (qua differential pricing) any constitutive identity in its logic... Constituting the identityless increase in aggregate capital-power, enfuturing the present in the autosabotage of pricing, the misfortune of the archderivative is the historicity of capital-power. (797-98)

If capitalism has no identity, and if derivatives, that monstrosity that has been so much empowered by money markets, are an "identityless increase," what can an American studies focused on the economy do? Before answering, I quote Wai Chee Dimock's comment on how Hurricane Katrina posed a challenge to American studies:

At this critical moment, it is especially important for the humanities to rethink its space and time coordinates, to take up questions that might once have seemed far removed - coming not only from hitherto extraneous fields such as earth and planetary sciences but also from hitherto extraneous populations, not traditionally included in the discipline. (154)

Facing a different hurricane, the one that has subsumed us under the command of volatile money, which, albeit not as visible as Katrina, is as devastating as natural disasters, I fully agree that our disciplinary practice has to rethink its premises and take up issues and questions which traditionally were not on the agenda. Perhaps there is no better position than from within American studies to do this. If to do this and to think the command of money necessitates the abandoning of the discipline and venturing forth into post-disciplinarity, I think the bargain is worth making. ${ }^{20}$

20 Although Peter Gowan does not use the term I go back to him in order to hint at what it might mean. In the Preface to his book, Gowan writes, "Many of the real dynamics seem to work in zones which fall between the territories covered by professional academic social science disciplines, whether economics or political science" $(\mathrm{x})$. Straying into that "be- 


\section{Works Cited}

Amatao, Massimo, and Luca Fantacci. The End of Finance. Cambridge: Polity Press, 2012. Print.

Arrighi, Giovanni. The Long Twentieth Century: Money, Power, and the Origins of Our Times. London: Verso, 2002. Print.

Assetto, Valerie J. The Soviet Bloc in the IMF and the IBRD. Boulder: Westview P, 1988. Print.

Bockman, Johana. Markets in the Name of Socialism: The Left-Wing Origins of Neoliberalism. Stanford: Stanford UP, 2011. Print.

Castronovo, Russ and Susan Gillman, eds. States of Emergency: The Object of American

Studies. Chapel Hill: The U of North Carolina P, 2009. Print.

Chossudovsky, Michel. "How the IMF Dismantled Yugoslavia.” Web. 12 Dec. 2015. <http://www.monitor.net/monitor/9904a/yugodismantle.html>

Denning, Michael. The Cultural Front: The Laboring of American Culture in the Twentieth Century. London: Verso, 2011. Print.

Dimock, Wai Chee. "World History according to Katrina." Castronovo and Gillman $143-60$.

Dyker A. David. Yugoslavia: Socialism, Development and Debt. London: Routledge, 1990. Print.

Ellerman, David. "Lessons from Eastern Europe's Voucher Privatisation.” Challenge 44.4 (2001): 14-37. Print.

Fluck, Winfried. “Theories of American Culture (and the Transnational Turn in American Studies).” REAL 23 (2007): 59-77. Print.

Gibbs, David N. First Do No Harm: Humanitarian Intervention and the Destruction of Yugoslavia. Nashville: Vanderbilt UP, 2009. Print.

tween," one lets unfold problematics that cannot be understood by disciplinary parameters. Concerning money and derivatives, I recommend to the reader schooled in the humanities Malik's “The Ontology of Finance," particularly those explanations where the author calls upon Derrida to explain the workings of this financial instrument. I truly wonder how many economists are equipped to appreciate Derrida just as I wonder how many readers of Derrida seriously engage economics. That non-meeting is the place I believe we should be headed towards if we seek to address the complexity that emerges after the disavowal of disciplinary dictates. 
Gligorov, Vladimir. “Defaults in Yugoslavia with Greece in mind.” 2015. Web. 12 Dec. 2015. $<$ http://wiiw.ac.at/defaults-in-yugoslavia-with-greece-in-mind-n-100.html>

Gowan, Peter. The Global Gamble: Washington's Faustian Bid for World Dominance. London: Verso, 1990. Print.

Grgas, Stipe. “American Studies as a Contemporary Disciplinary Practice." 2014a. Web. 12

Dec. 2015. <http://www.sicjournal.org/ArticleView.aspx?aid=261>

---. Američki studiji danas: identitet, kapital, spacijalnost. Zagreb: Meandar, 2014b. Print.

Heller, Agnes, and Ferenc Feher. The Grandeur and Twilight of Radical Universalism. New

Brunswick and London: Transaction Publishers, 1991. Print.

Holmes, Brian. “The Philosophy of Money.” Web. 12 Dec. 2015. <https://brianholmes. wordpress.com/2011/08/12/the-philosophy-of-finance>

Hudson, Michael. Super Imperialism: The Economic Strategy of American Empire (1972).

London: Pluto Press, 2003. Print.

Jakovina, Tvrtko. Američki komunistički saveznik: Hrvati, Titova Jugoslavija i Sjedinjene Američke Države 1945.-1955. Zagreb: Profil, 2003. Print.

Konings, Martijn. The Development of American Finance. New York: Cambridge UP, 2011. Print.

Lavigne, Marie. The Economics of Transition: From Socialist Economy to Market Economy. London: Palgrave Macmillan, 1999. Print.

Lewis, R.W.B. The American Adam. Chicago: Chicago UP, 1959. Print.

Malik, Suhail. "The Ontology of Finance: Price, Power and the Arkhederivative." Collapse

Vol VIII: Casino Real. Ed. Robin Mackay. Falmouth, UK: Urbanomic, 2014. 629811. Print.

Marazzi, Christian. "Money in the World Crisis: the New Basis of Capitalist Power". 1976.

Web. 12 Dec. 2015. <https://libcom.org/library/money-world-crisis-christianmarazzi-zerowork>

Marx, Karl. Grundrisse. Trans. Martin Nicolaus. London: Penguin Classics, 1973. Print.

---. Capital Volume I. Trans. Ben Fowkes. London: Penguin Classics, 1976. Print.

---. Capital Volume II. Trans. David Fernbach. London: Penguin Classics, 1978. Print.

Marx, Leo. The Machine in the Garden. New York: Oxford UP, 1964. Print.

McClintock, Anne. "Paranoid Empire: Specters from Guantanamo and Abu Ghraib." Castronovo and Gillman 70-88. 
Meier, Viktor. Yugoslavia: A History of its Demise. London and New York: Routledge, 1999. Print.

Miller, Perry. Errand into the Wilderness. 1956. Cambridge, Massachusetts: Harvard UP, 1984. Print.

Nash Smith, Henry. Virgin Land. Cambridge, Massachusetts: Harvard UP, 1978. Print.

Panitch, Leo, and Sam Gindin. The Making of Global Capitalism: The Political Economy of American Empire. London: Verso, 2012. Print.

Pease, Donald. "Re-thinking American Studies after US Exceptionalism.” American Literary History 21.1 (2009): 19-27. Print.

Prasad, Eswar S. The Dollar Trap: How the U.S. Dollar Tightened Its Grip on Global Finance. Princeton and Oxford: Princeton UP, 2014. Print.

Ritchl, Albrecht. "Calling Germany on its hypocrisy in the Eurozone debt crisis." Web. 12 Dec. 2015. <http://www.lse.ac.uk/researchAndExpertise/ researchImpact/PDFs/germany-hypocrisy-eurozone-debt-crisis.pdf>

Shih, Shu-mei. "Is the Post- in Postsocialism the Post- in Posthumanism." 2012.

Web. 12 Dec. 2015. <http://ccat.sas.upenn.edu/Complit/post-45/shih postsocialism_2012.pdf>

Starobin, Paul. “What Went Wrong." National Journal (December 1999). Web. 12 Dec. 2105. <http://janinewedel.info/media_nationaljournal.pdf>

Stiegler, Bernard. For a New Critique of Political Economy. Cambridge: Polity P, 2009. Print. van der Linden, Marcel, and Karl Heinz Roth. Beyond Marx: Theorising the Global Labor Relations of the Twenty-First Century. Chicago: Haymarket Books, 2014. Print. Varoufakis, Janis. “How Europe Crushed Greece.” The New York Times, September 8, 2015. <http://www.nytimes.com/2015/09/09/opinion/yanis-varoufakis-how-europecrushed-greece.html>

Vogl, Joseph. “The Sovereignty Effect: Markets and Power in the Economic Regime.” Qui Parle: Critical Humanities and Social Sciences 23.1 (2014): 125-55. Print.

Warren, Kenneth W. "Taking the Measure of the Black Atlantic." States of Emergency: The Object of American Studies. Castronovo and Gillman 116-23.

Wegner, Phillip E. Life Between Two Deaths, 1989-2001: U.S. Culture in the Long Nineties.

Durham \& London: Duke UP, 2009. Print.

Williamson, John, ed. The Political Economy of Policy Reform. Washington: Institute for 
International Economics, 1994. Print.

Woodward, Susan L. Balkan Tragedy. Washington: The Brookings Institute, 1995. Print.

---. "The Political Economy of Ethno-Nationalism in Yugoslavia." Socialist Register 39 (2003): 73-92. Print. 